\title{
Modeling of the Destination Image to the Trip Quality and Perceived Value in Bandung
}

\author{
Devita Gantina ${ }^{1}$, Anita Swantari ${ }^{2}$ \\ ${ }^{1,2}$ Sekolah Tinggi Pariwisata Trisakti, Jakarta, Indonesia \\ Email : ${ }^{1}$ devita@stptrisakti.ac.id, ${ }^{2}$ anitaswantari@stptrisakti.ac.id
}

\begin{abstract}
This study explains that Destination image can give you confidence, impression and perception of the destination. This study also proves the theory about the influence of destination image on trip quality, and perceived value. During the research, a total of 100 respondents completed the survey. carried out on visitors who come to the city of Bandung Research variables have good validity and reliability, the concept of models and hypotheses were tested using Lisrel 8.7. The results showed that there are two hypotheses that proved as follows: Destination image has positive and significant effect on perceived Value, Destination image has positive and significant effect trip quality. Findings of this research can be useful to managers of tourism in Bandung to assist in developing effective strategies to attract and retain visitors who come to the city. For the future research try to research by international visitor to know about their perception in destination
\end{abstract}

Keywords - Destination Image; Perceived Value; Trip Quality

\section{INTRODUCTION}

Tourism industry is a unique combination between various factors so that operational planning of a destination is different from other economic sectors. A tourist destination is a product but it has many links with diverse stakeholders, with the objectives and requirements vary. A destination is always different in size, attractiveness and benefits offered to tourists, in fact no two or more destinations can be equally enforced by tourists "Tourism management should refer to management principles that emphasize the values of nature, culture, community and social values that enable tourists to enjoy tourism activities and benefit the welfare of the local community" (Pitana and Diarta, 2009:81).

Successful tourism can increase revenue, employment and foreign exchange. How to attract tourists to re-visit and or recommend a destination to others is complicated for the successful development of the destination. Destination image gives influence to the desire of tourists to visit. Ashworth \& Goodall, 1988 (in Chen, 2006:2) argued that :"Destination image plays two important roles in behaviors: (1) to influence the destination choice decision-making process and (2) to condition the after-decision-making behaviors including participation (on-site experience), evaluation (satisfaction) and future behavioral intentions (intention to revisit and willingness to recommend)"

In the age of almost two centuries, the city of Bandung must have a very long history. Historical evidence that the city of Bandung is a potential city seen from a number of historical buildings inherited past as a source of artifacts. Therefore, the city of Bandung is also dubbed as Museum of Architecture of Ancient Buildings, not to mention other nicknames such as City of Artists, City of Education, City Tourism, City Services, City Culinary Tour, Creative City. The emergence of such epithets is not without reason because it is out of town Bandung has been born luminaries, both of education and the arts.

The number of potential owned and the variety of tourism industry produced city of Bandung, Bandung should be a city that is advanced in the field of tourism. However, it seems that the existing attraction has not been well managed and developed when the problem of tourism in the present has become a focal point of hope for foreign exchange income is large enough not only for the city of Bandung itself but also for the country. In fact, at the age that is not young anymore Bandung has become a chaotic city, which if left people will be reluctant to come to the city of Bandung. Until now, "Kota Kembang" or Paris van Java is still a public nickname for the city of Bandung. This positive image should be maintained because as an industry, tourism requires a marketing effort in which the image of the brand image in order to market tourism as a commodity to be sold to tourists. 
Every destination has a specific brand image, that is mental maps of a person to a destination that contains beliefs, impressions, and perceptions. The image formed in the tourism market is a combination of various factors in the destination (such as weather, landscapes, safety, health, sanitation, hospitality, etc.). On the one hand, the image has a great influence as the information received by the prospective traveler and in the other Party the image is a fantasy of each tourist who although not reel, but its existence is very important in influencing the decision of potential tourists to travel to one region.

The importance of the role of brand image can be seen from the understanding that tourism is an imaging-based industry, because the image is able to bring potential tourists to the world of symbols and meaning. Even the image or image can be said to play a more important role than the visible tourism resources.

\section{LITERATURE REVIEW}

According to Jenkins (1999: 2) it is said that: "the expression of all objective knowledge, impressions, prejudices, imaginations, and emotional thoughts of an individual or group might have a particular place". Which means the image of the destination is an expression of all objective knowledge, impression, prejudice, imagination and the emotional mind of the individual or group towards a particular destination. Crompton said (in Marrino, 2007:3) "destination image are the sum of all those emotional qualities like experiences, beliefs, ideas, recollections and impressions that a person has of a destination".

From some of destination definition above it can be deduced that the Destination Image is the sum of all the emotional qualities such as experience, beliefs, thoughts, memories, emotional mind individual or group to a particular destination. in Chon 1992, Baloglou and Bringmerg 1997 (in Buhalis, 2000: 6), "Before people go to a destination they develop the image and a set of expectations based on previous experience, word of mouth, press reports, advertising and common beliefs". Hunt, 1975, Phelps, 1986, Fakeye dan Crompton, 1991 (in Ibrahim and Gill, 2005: 2). "Destination image has been defined as an individual's overall perception or total set of impressions of a place".

The purpose of the destination image by Bonn et al in Sirgy and Su (2000:340) " Destination image is composed of various attributes that can be divided in controllable attributes (destination product, price, place and promotion) and uncontrollable ones (personal characteristics). Destination image is influenced by the environmental attributes - atmospheric attributes (landscapes, historical attractions, infrastructure, accommodation and facilities) and service attributes. Tourism managers can use these attributes to manipulate potential tourists' destination image formation. But it is also important to understand the images potential tourists have already had about the destination. This can help in developing of positional strategies to alter these images."

Lawson and Baud Bovy 1977 (dalam Jerkins,1999: 2), A destination image is 'the expression of all objective knowledge, impressions, prejudice, imaginations, and emotional thoughts an individual or group might have of a particular place. Another thing with Ngashima (1970) explained that the image of the destination is a picture, reputation and stereotype owned by businessmen and consumers of certain country products. This image was created by various variables as product representation, characteristics of country, economic and political background, history and tradition.

To illustrate the process of image formation of a kotler's destination, (1993: 2) uses strategic image management as a process defined as a quest for destination image among visitors. Segmentation process and targeting the specific image and demographic of the visitor, positioning the benefit of destination to support the image that has been formed or create a new image.

Chen \& Sai (2006:2) "Trip quality is the visitor's assessment of the standard of the service delivery process in association with the trip experience" The definition states that trip quality is a standard assessment of tourists for services received and then compare with previous travel experiences or travel experiences on other similar destinations. 
According to Chen 2006 (in Buhalis, 2000: 2) explains that trip quality measurements include 4 aspects: (1) Hospitality: the quality of travel judged by the hospitality and the quality of service received by the tourists, (2) the environment: assessed for the elements of the environment enjoyed by travelers during the trip, (3) transportation: quality of travel assessed for ease of reaching destination sites and (4) amenities quality of travel assessed on other supporting aspects so as to enhance travel and travel to be qualified and meaningful.

Chen \& Sai (2006:2) "Perceived value: the visitor's overall appraisal of the net worth of the trip, based on the visitor's assessment of what is received (benefits), and what is given (costs or sacrifice)". Zethaml, 1988 (in Rudiyanto, 14) defines the value of perception as an overall customer assessment of the products and services based on perceptions of what the customer receives and what the service provider provides.

\section{METHODS}

\section{A. Research Design}

This study adopted from research conducted by Ching Fu Ceng \& Dung Chui Sai (2006), which aims to determine the model of integrated tourist consumption process in the influence of the image of the destination of the quality of travel, and the value of perception in of Bandung city

This type of research is correlation study because they're interested in explaining the important variables related to the problem is whether the image influencing Destinations Travel Quality, and whether the image influencing Destinations Perceived Value.

\section{B. Data Collection}

Data were collected using two techniques, which are: (a) primary data collection through field observations and questionnaire (b) secondary data collection through literature studies and institutional survey. The collected data were then analyzed using descriptive and quantitative method. The study was conducted from November to December 2017. The questionnaire fill by guest who have to visited Bandung at September until November 2017. In this study the sampling by Accidental Sampling, i.e the process of sampling is done by chance without a certain consideration.

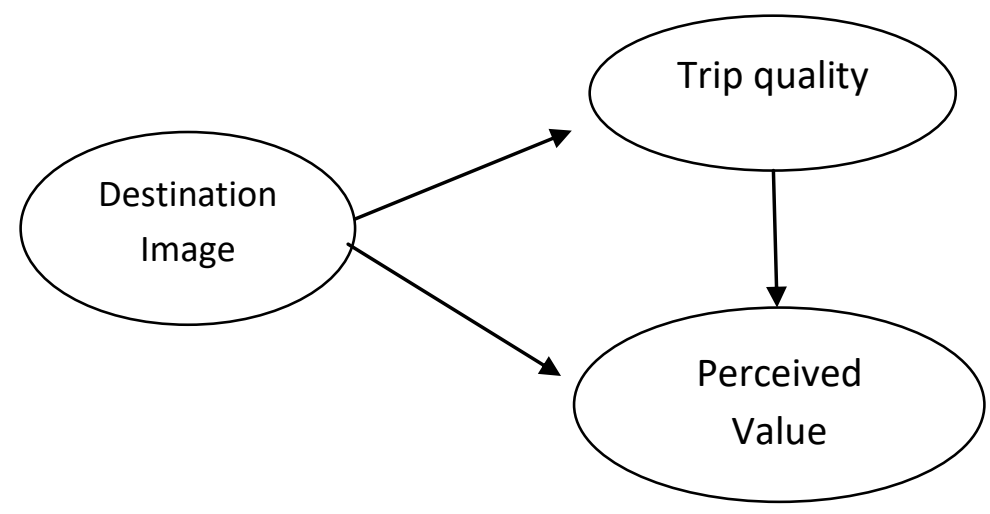

Fig.1. Research Framework

Sources : Chen and Tsai 2007 


\section{RESULTS AND DISCUSSION}

The Research of 'Modeling of the destination image to the trip quality and perseived value in Bandung, highlights how about the trip quality and perceived value of Tourist in Bandung city. Based on the data of respondents it can be explained that from a total of 330 respondents, the majority of respondents' age is twenty six years up to thirty five years. The gender is female, Occupation is government employee.

TABLE. I DESTINATION IMAGE

\begin{tabular}{|c|c|c|c|c|c|c|}
\hline & Item & $\mathrm{N}$ & Minimum & Maximum & Mean & $\begin{array}{c}\text { Std. } \\
\text { Deviation }\end{array}$ \\
\hline B 1 & A good shopping place & 330 & 3,00 & 5,00 & 4,3848 & ,57328 \\
\hline B 2 & Varied Gastronomy & 330 & 3,00 & 5,00 & 4,5455 & ,56174 \\
\hline B 3 & A good quality of life and clean & 330 & 2,00 & 5,00 & 4,2636 & ,55806 \\
\hline \multirow[t]{3}{*}{ B 4} & Spectacular lanscape & & & & & 69314 \\
\hline & & 330 & 2,00 & 5,00 & 4,0182 & \\
\hline & Valid N (listwise) & 330 & & & & \\
\hline
\end{tabular}

Source : (Primary Data 2017)

Among the various indicators of the latent variables of destination image, the average respondent's highest answer on indicator B2 (Varied Gastronomy), i.e with the average value $=4,5455$ while the lowest value is indicator B4 (Spectacular Lanscape) with an average rating of $=4,0182$.

The value of the indicator gives an illustration that in general visitors consider that Bandung City has a variety of culinary. This fact indicates that the measurement indicator identifies that the visitor is more appraised that the Bandung city has a culinary that varies with other products. In this case visitors assess the city of Bandung is a destination for a culinary tour, this is indicated by many culinary variations offered city of Bandung such as: Mie Kocok, lotek, sausage dishes, soto bandung brownies.etc.

TABLE. II TRIP QUALITY

\begin{tabular}{|c|c|c|c|c|c|c|}
\hline & Item & $\mathrm{N}$ & Minimum & Maximum & Mean & $\begin{array}{c}\text { Std. } \\
\text { Deviation }\end{array}$ \\
\hline $\mathrm{C} 1$ & Price of accommodation & 330 & 2,00 & 5,00 & 4,0152 & ,64512 \\
\hline $\mathrm{C} 2$ & Food and beverage of accommodation & 330 & 2,00 & 5,00 & 4,0394 & 63459 \\
\hline $\mathrm{C} 3$ & Service of Accommodation & 330 & 2,00 & 5,00 & 4,0303 &, 55048 \\
\hline $\mathrm{C} 4$ & Prices of food and beverage & 330 & 3,00 & 5,00 & 4,0515 &, 58378 \\
\hline C5 & Safety of activities & 330 & 2,00 & 5,00 & 4,0091 & ,66838 \\
\hline C6 & Cleanness of city & 330 & 2,00 & 5,00 & 3,7424 & ,72955 \\
\hline & Valid N (listwise) & 330 & & & & \\
\hline
\end{tabular}

Source : (Primary Data 2017) 
Among the indicators of the latent variables of the trip quality, the average respondent's answer was highest on the indicator C 4 (Prices of food and beverage), that is, the average value $=4.0515$ while the lowest value is the C6 indicator (Cleanness of city) with average value $=3,7424$

The value of the indicator gives an illustration that in general visitors consider that the city of Bandung has affordable food and beverage prices. whereas in the case of the lowest value can be seen that according to visitors who come to the Bandung city that the cleanliness of city of Bandung is considered less. This fact shows that the measurement indicator identifies that visitors are more choose because the price of food and beverages are very good.

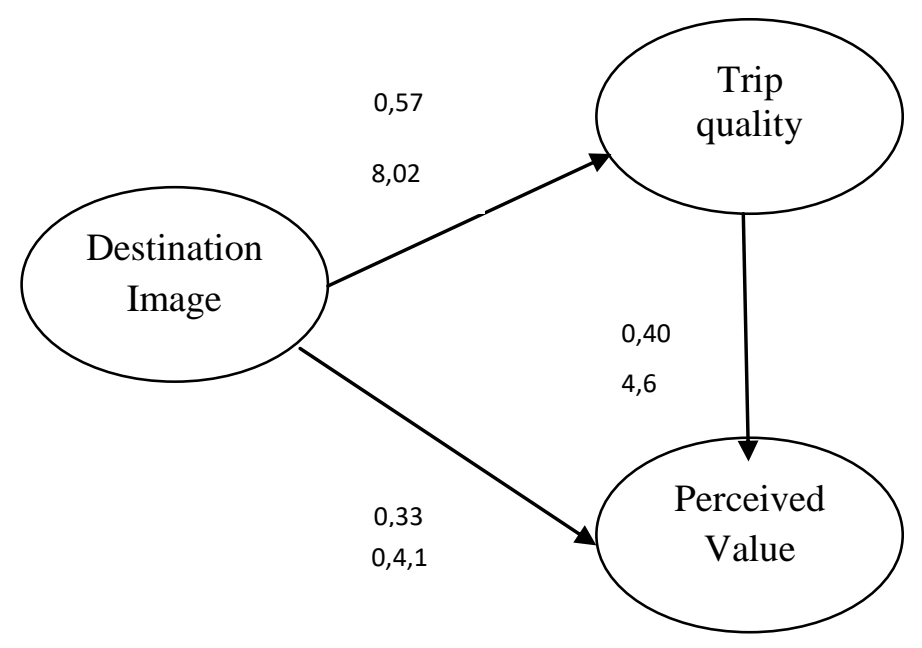

Figure 2. Model

Destination image variable significantly positive to Service Quality with t-value 4,60 and Standardized coefficient 0,57 , Service Quality variable have positive significant to Perceived value with t-value 4,60 and Standardized coefficient 0,40. The image of the destination Influence directly and positively to the Value of Tourist Perception of 0.33 and has the value of $\mathrm{O}, 23$. for indirect influence through travel Quality even if the value is low. The total effect value is 0.56 . This total effect is the highest value among the models

\section{Conclusion}

Destination image has positive and significant impact on trip quality. These results provide support for the first hypothesis that the better the Image Destination, The higher the perceived quality of the trip. This shows that improving the image of the destination will lead to increased quality of travel in the Bandung city.

Image destination positively and significantly influence to Perceived Value. This result provides support for the second hypothesis which states that The Better the Image of Destination, the higher the value of perception. This indicates that the improvement of destination image will cause the increasing of perception value by tourists who come to Bandung city.

\section{Recommendation}

In this study examined the Image destination in the Bandung city, then can be done similar research in other destinations. Other destinations are expected to improve the image of the destination because the image of the destination may affect some factors hat may influence travelers to visit again. 
Not only improve the image of the destination, the quality of the trip to a destination can affect tourists to visit again. The quality of the trip includes hospitality from the sights, attractions presented, good transportation to the sights, and adequate amenities.

\section{REFERENCES}

Ashworth, G., \& Goodall, B. (1988). Tourist images: Marketing considerations. In B. Goodall, \& G. Ashworth (Eds.), Marketing in the tourism industry. The promotion of destination regions (pp. 213-238). London: Croom Helm

Backman, S. J., \& Veldkamp, C. (1995). Examination of the relationship between service quality and user loyalty. Journal of Park and Recreation Administration, 13(2), 29-42.

Buhalis, D. D. (2000). Marketing the competitive destination of the future. Tourism Management, 21(1), 97-116

Chen, F.C, \& Tsai, D.C.,(2007). How destination image and Evaluative factors affect behavioral intentions?. Tourism Management. 28(7), 1115-1122

Jerkins, O.H., (1999). Understanding and Measuring Tourist Destination Images. International Journal of Tourism Researchch. 2. 1-1

Marino, E.D., (2007). The strategic dimension of destination image. An analysis of the french riviera image from The italian tourists' perceptions. Tourism Management.1-20

\section{http://torc.linkbc.ca/torc/downs1/WTOdefinitiontourism.pdf}

http://www.bandunqtourism.com/tododet.php?q=Taman\%20Ade\%20Irma\%20Suryani\%20\%28Tama n\%20Lalu\%20Lintas\%29

http://www.bandungtourism.com/tododet.php?q=Taman\%20Ade\%20Irma\%20Suryani\%20\%28Tama n\%20Lalu\%20Lintas\%29 